\title{
Effect of Copper Sulphate on Succinate Dehydrogenase and Lactate Dehydrogenase in the Selected Tissues of Fresh Water Fish, Catla Catla
}

*Dr. S. Sankar Samipillai ${ }^{1}$, U. Uma ${ }^{2}$

${ }^{1}$ Assistant Professor, PG and Research Department of Zoology, Govt. Arts College, Chidambaram, Tamil Nadu, India

${ }^{2} \mathrm{PG}$ and Research Department of Zoology, Govt. Arts College, Chidambaram, Tamil Nadu, India

\begin{abstract}
The present study is aimed to investigate the enzymological paprameters such as succinate dehydrogenase (SDH) and lactate dehydrogenase (LDH) in the brain, gill,liver and kidney tissues of fresh water fish, Catla catla exposed sublethal concentration of copper sulphate. The present study shows the level of succinate dehydrogenase was decreased and lactate dehydrogenase was increased in brain, gill,liver and kidney tissues of fresh water fish, Catla catla due to exposure of copper sulphate.The present study concludes that the copper sulphate affect the enzymological activities in fresh water fish, Catla catla.
\end{abstract}

Keywords : Copper sulphate, SDH,LDH, Catla catla

\section{INTRODUCTION}

Water pollution is a serious problem to all aquatic fauna and flora. In aquatic environment, pesticides may also cause several physiological and biochemical defects in fishes. The aquatic environment, where fish and other aquatic organisms live, is subjected to different types of pollutants from industrial, domestic and agricultural discharge systems thereby introducing stress to the living creatures. Stress is a general and non-specific response to any factor disturbing homeostasis. Stress reaction involves various physiological changes including alteration in blood composition and immune mechanisms[1,2].

Aquatic life is strongly influenced by physical properties of a water body. It is known that heavy metals as well as agro-pollutants are potentially harmful to the aquatic lives. The contamination of inland and surface waters and land/soil, due to the release of variety of chemicals may prove toxic to all classes of living organisms. Copper sulphate is widely used as an algaecide for controlling phytoplankton in fish ponds and lakes as well as a herbicide used in aquatic weed control since 1882[3]. Most of the heavy metals are micronutrients and they exert a prominent role in environmental deterioration. The heavy metal and pesticide contamination of aquatic ecosystems has increased manifold in the last few decades due to their extensive use in agricultural, chemical and industrial processes and is a real threat to the aquatic fauna. Among metals, copper is used in industries manufacturing organic chemicals, fertilizers, ironand steel works, electrical works, antifouling paints, pulp and paper industries, pesticides, fungicides and automobile accessories [4]. Copper contamination from normal and anthropogenic sources, like mine washing, agricultural leaching and proximate implementation appears as algaecide and molluscicide in the aquatic environment[5]. Copper toxicity and growth in three 
grassland species in the Netherlands. High densities of copper are observed in some ecological aquatic systems collecting vineyard runoff water and groundwater Copper is a trace element vital to life, but the toxic influence of water pollution with this metal on fish is now manifestly exhibited hematological and immunological parameters can be utilized as toxicity indices of xenobiotics.

Fishes are an important component of human nutrition, and those from contaminated sites present a potential risk to human health. Since fish occupy the top of the aquatic food chain, they are suitable bio indicators of metal contamination. Fishes are regarded as the most inductive factor in different studies for the estimation of heavy metals because they cannot escape from the detrimental effects of heavy metal pollution. In addition to this, often being at top of aquatic food chain, they eat concentrated large amounts of bio accumulated metals [6,7]. Fishes are the simple and reliable biomarker of copper pollution of aquatic bodies [8]. The metallic ion present in water enters the fish body and gets accumulated in various organs like liver and kidney[9].

The brain is an extremely heterogeneous organ with a large number of different neuronal and nonneuronal cell types, and extensive morphological differentiation and biochemical compartmenention within the cell [10]. Fish gills, which serve as the primary uptake site in fish for trace metals, represent the most important targets when exposed to elevated levels of ambient metals [11]. Gills are the vital organs for respiration of fish, which establish a direct contact with the medium through which the pollutants largely enter into the body[12]. The gills are the first organs to be affected by the toxicants among the other organs due to fish nature. The gills serve as the most sensitive index to monitor environmental alterations[13]. Liver is one of the most multifaceted and active organs in higher animals. In a vertebrate body, the liver is the most important target organ as it is the chief metabolic and detoxification center. It is the site for numerous and varied metabolic activities, including synthesis of bile which contains bile salts, bile pigments, cholesterol and lecithin $[14,15]$.The kidney as an organ is mainly concerned with the removal of waste materials. [16] has reported that most toxicants are excreted through the kidney when exposed to pesticides and heavy metals. The pathological effects of heavy metals on kidney of various animals have been studied by several worker [17]. In fish, as in higher vertebrates the kidney performs an important function related to electrolyte and water balance and the maintenance of a stable internal environment. The kidney excretes nitrogen containing waste products from the metabolism such as ammonia and urea.

\section{METHODS AND MATERIAL}

\section{Procurement of experimental animal}

The fresh water fish, Catla catla were collected from the fish farm located in Puthur, Nagai District, $15 \mathrm{~km}$ away from the Govt, Arts, College, Chidambaram. These fishes were brought to the laboratory and transferred to the rectangular fiber glass tanks $(100 \mathrm{X} 175 \mathrm{~cm})$ of 500liters capacity containing chlorine free aerated well water.

\section{Acclimatization of animals}

The fresh water fish, Catla catla were acclimatizad for a minimum period of 15 days in the laboratory conditions at room temperature $\left(28 \pm 1^{\circ} \mathrm{C}\right)$ before subjecting them for screening test. These fingerlings were fed with artificial food pellets on alternative days and the water renewed every 24 hours. The tanks were rinsed with potassium permanganate or acroflavine $(2 \mathrm{mg} / 1)$ to prevent fungal attack. The fresh water fish, Catla catla were critically screened for the sings disease, strees, physical damage and 
mortality. The injured, severely diseased, abnormal and dead fishes were discarded. The feeding was discontinued 24 hours before the beginning of the experiment to reduce the excretory products in the test trough as suggested by[18]. During the acclimatization, the fishes were reared in tank until there was less than 10 percent mortality in 4 days period to the beginning of the as suggested by[19]. The water in the experimental trough was changed daily and also aeration was stopped to avoid the possible oxidation of the toxicants.

\section{Experimental design}

The toxicant exposure was done by 24 hour or renewal bioassay system. For analysis sub lethal toxicity, 2 groups of 10 fish each were exposed separately and arsenic trioxide(2.73ppm : $10 \% 96$ hours $\left.\mathrm{LC}_{50}\right)$. Solution prepared in well water. The experimental medium was prepared by dissolving Copper sulphate at $30 \mathrm{ppm}$ having dissolved oxygen $5.8 \mathrm{ppm}, \mathrm{PH} 7.4$, water hardness $30.3 \mathrm{mg} / 1[20]$ and water temperature $28 \pm 2 \mathrm{C}$. Each group was exposed to 501 of the experimental medium. Parallel groups of 10 fish each were kept in separate aquatic containing 501 of well water as control. Feeding was allowed in the experimental as well as control groups every day for a period of 3 hours. Before the renewal of the medium through out the denature of the experimental.

\section{Estimation of $\mathrm{LC}_{50}$ value}

Period to the commencement of the experiment, 96hr medium lethal concentration as $\left(96 \mathrm{hr} \mathrm{LC}_{50}\right)$ of copper sulphate for Calta calta was estimated [21] and $24 \mathrm{hrs}$ renewal bioassay system and was found.

\section{Measurement of dehydrogenase activity}

\section{Preparation of samples}

After experiment, the fish each from the respective experimental as well as control groups were secrificed. The brain, gills, liver and kidney were isolated from the fish and used for various study.

The tissues were isolated from the animal in the cold room and 5 per cent homogenate was prepared in $0.25 \mathrm{~m}$ sucrose solution and centrifuged at $2500 \mathrm{rpm}$ for 15 minutes to remove cell debris. The supernatant was used for the enzyme assay.

\section{Preparation of succinate dehydrogenase (SDH) reaction mixture}

Succinate dehydrogenase was estimated by the method of [22]. In $10.0 \mathrm{ml}$ clean dry test tube the following reaction mixture was added. The reaction mixture consisting of $1.0 \mathrm{ml}$ of $\mathrm{Na}-\mathrm{K}$-phosphate buffer $(0.1 \mathrm{M} \mathrm{pH} 7.4) 0.5 \mathrm{ml}$ of sodium succinate $(0.1 \mathrm{M} \mathrm{pH}$ 7.4) $0.5 \mathrm{ml}$ of 0.5 per cent INT (2-p-iodophyeneyl)-3(p-nitrophenyl)-5-phenyl tetrazolium chloride was added.

\section{Preparation of Lactate Dehydrogenase (LDH) reaction mixture:}

Lacate dehydrogenase was estimated by the method of Govindappa and swami, (1965).In a $10 \mathrm{ml}$ clean test tube the following reaction mixture consisting of $1.0 \mathrm{ml}$ of $0.1 \mathrm{M} \mathrm{Na}-\mathrm{K}$-phosphate buffer, $0.5 \mathrm{ml}$ of 0.1 $\mathrm{M}$ lithium lactate, $0.5 \mathrm{ml}$ of 5 per cent INT in water was added.

\section{Estimation of Dehydrogenase activity}

All the above dehydrogenase reactions were initiated by the addition of $1.0 \mathrm{ml}$ tissue homogenates. The samples were incepted at $37^{\circ} \mathrm{C}$ for one hour and the reactions were stopped by the addition of $6.0 \mathrm{ml}$ of acetic acid. The formazan formed was extracted with $6.0 \mathrm{ml}$ of toluene by keeping the tubes every night in a reingerator at $5^{\circ} \mathrm{C}$. The colour was read at $495 \mathrm{~nm}$ in double beam spectrophotometer. The 
dehydrogenase activity was expressed in $\mathrm{u}$ moles formazan formed/mg protein/hour.

\section{Statistical analysis}

Statistical significance was evaluated by using ANOVA followed by Duncan Multible Range Test (DMRT) [23].

\section{RESULTS AND DISCUSSION}

\section{RESULTS}

\section{Level of succinate dehydrogenase in brain tissue}

In the brain tissue of normal fish, the level of succinate dehydrogenase was $35.11 \pm 1.06 \mu$ mole formazone formed/mg of protein/hr. During the sublethal concentration of copper sulphate, the level of succinate dehydrogenase was decreased upto $18.55 \pm 0.12 \mu$ mole formazone formed/mg of protein/hr when compared to control. (Fig.1).

\section{Level of succinate dehydrogenase in gill tissue}

The level of succinate dehydrogenase was $49.22 \pm 1.82$ $\mu$ mole formazone formed/mg of protein/hr. in the control gill tissue. at sub lethal concentration of copper sulphate, the gill tissue showed the decreased trend of exposed to copper ,the level of succinate dehydrogenase content was decreased upto $21.26 \pm 1.82 \mu$ mole formazone formed $/ \mathrm{mg}$ of protein/hr. (Fig.1).

\section{Level of succinate dehydrogenase in liver tissue}

In te normal liver tissue, thee level of succinate dehydrogenase content was $41.66 \pm 1.65 \mu$ mole formazone formed $/ \mathrm{mg}$ of protein $/ \mathrm{hr}$ when the fish exposed to copper sulphate, the level of succinate dehydrogenase content was decreased upto 20.76 $\mu$ mole formazone formed/mg of protein /hr. (Fig.1).

\section{Level of succinate dehydrogenase in kidney tissue}

The level of succinate dehydrogenase present the kidney tissue of normal fish was $41.76 \pm 1.65 \mu$ mole formazone formed/mg of protein/hr. The level of succinate dehydrogense was decreased upto $21.79 \pm 1.13 \mu$ mole formazone formed $/ \mathrm{mg}$ of protein/hr when the fish exposed with sub lethal concentration of copper sulphate (Fig.1).

\section{Level of lactate dehydrogenase in brain tissue}

In the brain tissue of normal fish, the level of lactate dehydrogenase was31.42 $\pm 1.99 \mu$ mole formazone formed/mg of protein/hr. During the sublethal concentration of copper sulphate, the level of lactate dehydrogenase was increased upto18.68 $\pm 1.61 \mu$ mole fotmazone formed/mg of protein/hr when compared to control (Fig.2).

\section{Level of lactate dehydrogenase in gill tissue}

The level of lactate dehydrogenase was $39.19 \pm 1.86$ $\mu$ mole formazone formed $/ \mathrm{mg}$ of protein $/ \mathrm{hr}$. in the control gill tissue. At sub lethal concentration of copper sulphate, the gill tissue showed the increased trend of lactate dehydrogenase $(59.01 \pm 1.26 \mu$ mole formazone formed/mg of protein /hr) (Fig.2).

\section{Level of lactate dehydrogenase in liver tissue}

In the normal liver tissue, the level of lactate dehydrogenase was $58.26 \pm 1.52 \mu$ mole formazone formed/mg of protein/hr when th fish exposed to copper sulphate, the level of lactate dehydrohense was increased upto $41.12 \pm 1.61 \mu$ mole formazone formed/mg of protein/hr. (Fig.2).

\section{Level of lactate dehydrogenase in kidney tissue}

The level of lactate dehydrogense present in the kidney tissue of normal fish was $20.39 \pm 1.64 \mu$ mole formazone formed/mg of protein/hr. The level of lactate dehydrogense was increased upto $30.01 \pm 1.20$ $\mu$ mole formazone formed/mg of protein/hr when the fish exposed with sub lethal concentration of copper sulphate (Fig.2). 


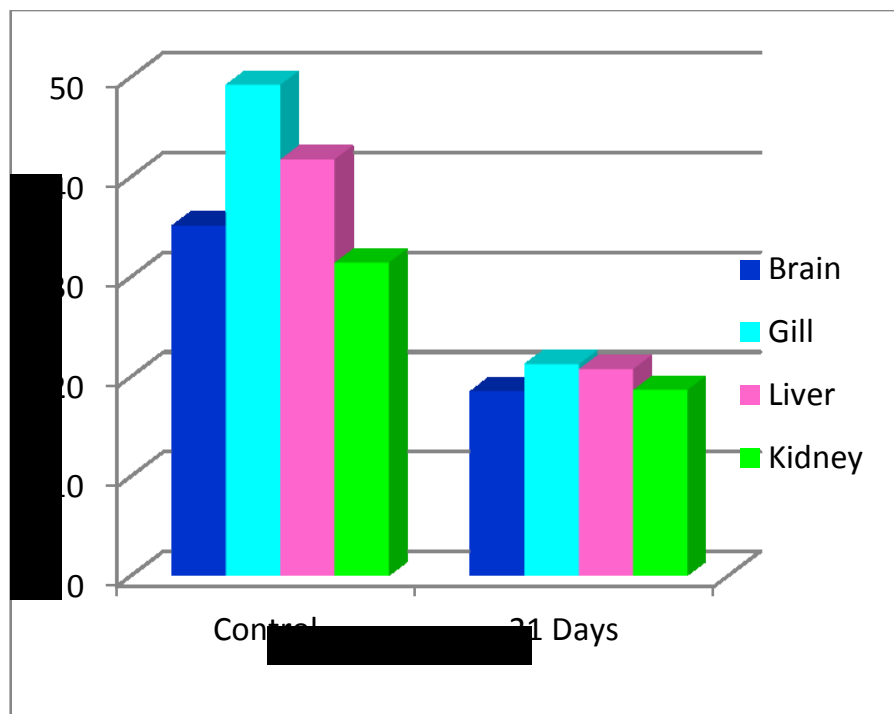

Fig 1. Level of succinate dehydrogenase in the selected tissue of fresh water fish Catla catla exposed with sub-lethal concentration of copper sulphate

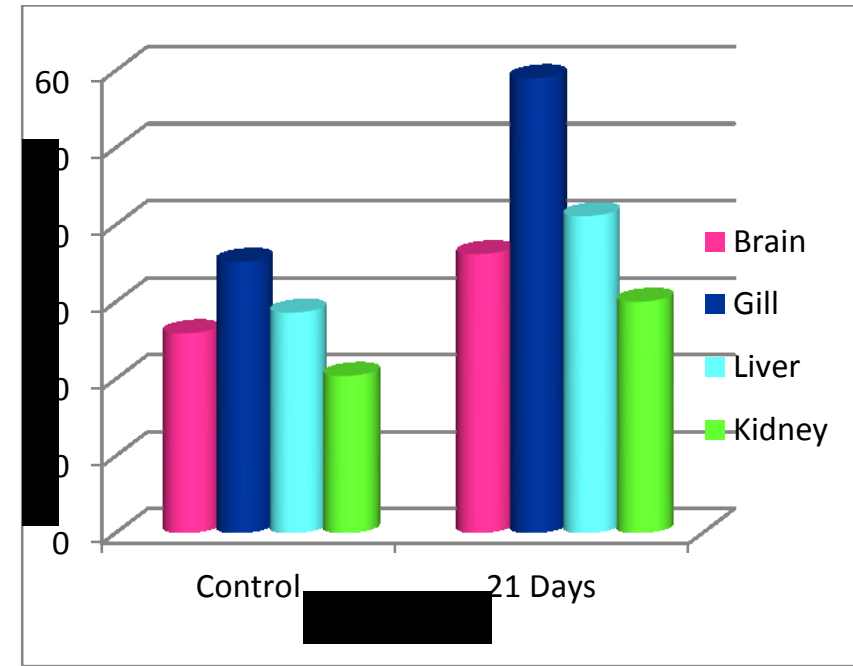

Fig 2. Level of Lactate dehydrogenase in the selected tissue of fresh water fish Catla catla exposed with sub-lethal concentration of copper sulphate

\section{DISCUSSION}

Heavy metals are recognized as one of the most hazardous environmental pollutants and are toxic to many living organisms[24]. Copper sulphate is known for their action on biological tissues [25]. Metal ions once absorbed into the body are capable of reacting with a variety of active binding sites and then disturbing the normal physiology of the organism which may lead to the death of organism. The toxic effect of heavy metals on enzyme system depends on the capacity of toxicants to react with ligands [26].The harmful pollutants may cause injury to organism and the damaged tissues shall dysfunction, Which result in quantitative altered enzyme activity [25]. The succinate dehydrogenase (SDH) is an important enzymes of Kreb's cycle whose quality changes are significant during certain pathological conditions [26]. Sucinate dechdrogenase (SDH) is the oxidative enzyme which was drastically affected by the action of heavy metals. Succinic acid dehydrogenase ( $\mathrm{SDH})$ is chosen as a representative of metabolic enzyme. The Lactate dehydrogenase (LDH) is an important role in carbohydrate metabolism and converts the lactate to pyruvate. It is generally associated with cellular metabolic activity and inhibition in enzyme activity may be due to the imbalance or intracellular action of the metal subsequent to initial damage caused to the plasma membrane. Lactate dehydrogenase (LDH) is present in most of the animal tissues and is involved in the inter conversion of lactic acid to pyruvic acid and acts as a vital enzyme between glycolytic pathway and tricarboxylic acid cycle.

In the present study the level of succinic acid dehydrogenase decreased and lactate dehydrogenase increased in brain, gill, liver and kidney tissue of Catla catla exposed to sublethal concentration of copper sulphate. This suggests that a inhibited mitochondrial oxidation of succinate which may lead to drop in energy production and the suppression of SDH activity indicates the impairment of oxidative metabolic cycle and hence relies on amaerobic glycolysis may be increased to meet its energy demands. Similarly, [27] have reported a decrease in the SDH activity and an increase in the LDH activity in the liver tissue of Channa punctatus exposed to cadmium and copper. [28] have reported that a decreased in SDH activity and increase in $\mathrm{LDH}$ 
activity in the gill and liver tissues of Anabs scandens exposedto lead nitrate. [29] have observed that the level of SDH activity decreased in the liver tissue of animals exposed to metal. They reported a metabolic shift from aerobic to anaerobic due to metal actions. [30] observed alterations in oxidative metabolism of Viviparous bengalensis after exposure to heavy metal. [31] reported that the level of SDH activity in Lamellidents marginalis exposed to malathion. More et al.,(2005) have observed that the level of SDH activity decreased in Lamellidents marginalis exposed to heavy metal. They also reported that the anaerobic activity of the cells due to pollution stress has reversed on example of physiological and biochemical adaptation.

The decrease in SDH activity might be suggestive of the weakening of biochemical difference which in turn could be the results of tissue damage. [32] has observed a reduction in SDH activity in the liver tissue of Mystus vittatus exposed to copper. [33]) have reported that the elevation in LDH and suppression in SDH activities in liver tissues of Labeo rohita exposed to copper. [34] have reported they an increase in LDH alters increased permeability of cell and necrosis. The significant elevation of LDH suggests that puruvate, the end product of glycolysis is not routed to kreb's cycle but product or glycolysis is not routed to kreb's cycle but to the lactic acid cycle, [35]) reported that the $\mathrm{LDH}$ increased in muscle of Oreochromis mossampicus exposed to cadmium.

\section{REFERENCES}

[1]. Svoboda, M, 2001. Stress in fishes (a review). Bull. Vurh Vodnany. 4:169- 191.

[2]. Witeska, M and Kosciuk.B 2003. Changes in common carp blood after short-term zinc exposure. Environ. Sci.. Pollut. Res., 3:15-24

[3]. Carbonell GJ, Tarazona V. (1993). A proposed method to diagnose acute copper poisoning in cultured rainbow trout, Oncorhynchus mykiss. Sci. of Total Environ. 2: 1329-1334.

[4]. Singer.C, Zimmersann.S, Induction of heat shock proteins in the zebra muscle (Dreissena polymorpha) following exposure to platinum group meyals (platinum, palladium and rhodium): Comparison with lead and cadmium cadmium exposures. Aquatic Toxicology. 75: 65-75. 2005.

[5]. Dueck.T.A, Tensen.D, Duijff.B, Pasman.F. Nutrient fertilization, copper toxicity and growth in three grassland species in the Netherlands. Journal of applied ecology. 1987:1001-10.

[6]. Rashed.M.N (2001). Monitoring of environmental heavy metals in fish from Nasser Lake. Environ. Int. 27, 27-33.

[7]. Olaifa.F.E, Olaifa.A.K, Adelaja.A.A, Owolabi.A.G 2004. Heavy metal contamination of Clarias gariepinus from a Lake and Fish farm in Ibadan, Nigeria. African J. Biomed. Res. 7, $145-148$.

[8]. Taylor, LN., Mc Geer.J.C, Wood.C.M and Mc Donald.D.G 2000. Physiological effects of chronic copper exposure to rainbow trout (Oncorhychus mykiss) in hand and soft water, evaluation of chronic indicators. Environ. Toxicol. Chem., 19, 2298-2308.

[9]. Shukla, V., M. Dhankhar, J. Prakash and K.V. Sastry.2007. Bioaccumulation of $\mathrm{Zn}, \mathrm{Cu}$ and $\mathrm{Cd}$ in Channa punctatus. J. Environ. Biol., 28, 395397.

[10]. Rana, S.V.S., Singh.R and Verma.S, 1996. Protective effects of few antioxidants on live functions in rats treated with cadmium and mercury. Int. J. Exp. Biol., 34:177-179.

[11]. Newman, M.C and Jagoe.C.H, 1994. Ligands and the bioavailability of metals in aquatic environments. in: Hamelink, J.L., Landrum, P.F., Bergman, H.L., Benson, W.H. (Eds.), bioavailability: physical, chemical, and 
biological interactions.Lewis publications, Boca Raton, Fl,39-62.

[12]. Mount.D.I, Warner.R.E, 1962. A serial-Dilaion Apparatus for Contonous Delicery of Various Concentration of Material in Water. U.S Public Health Serv.Publ No.999- WP-23.

[13]. Mahajan,C.L. and Juneja,C.J. 1979. Ind. J. Environ. Health 21:162. In Proceedings of the National Academy of Science India. 58B (1): 5565.

[14]. Bhattacharya, S and Mukherjee, K, 1976. Activity of the hepatopancreatic protease and esterase in fish exposed to industrial pollutants. Comp. Physiol. Ecol., 1:45-56.

[15]. Abbasi, S.A and Krishnan. S, 1993. The new Japanese pesticide Cartap (Pandan) in Clarias gariepinus adults exposed to aqueous and ethanolic extracts of Parkia biglobosa pods. Afr. J. Biotechnol., 10: 234-240.

[16]. Lu, 1985. Basic toxicology fundamental, target organ and risk assessment. Hemisphere Publishing Corporation, Washington.

[17]. Rajamanickam, C., 1992. Effect of heavy metal copper on the biochemical contents, bioaccumulation and histology of the selected certain in the freshwater fish, Mystus vittatus (bloch)., Ph.D. Thesis. Annamalai University, India.

[18]. Arrora,H.C,Sharma.V.P,Chattopathya.S.N and Sinha.L.P,1972. Bioassay studies of some commercial organic insecticides part-III. Trials of Cirrhinus mirgala with 6 insecticiders. Indian J.Environ.Hlth,14(4):352-359.

[19]. Anderson, R.I., 1977, Chironomic toxicity testBiological back-ground and procedure .American Soc. For testing and materials, Blacksburg, VA.27-29.

[20]. APHA, American public health association, AWWA, American water Association and WPCF (water pollution and Fedatation) 1992. Standard methods for the examination of water and waste water 19th Edition. Washinagton. DC.

[21]. Hamilton, M.A.; Russo, R.C.; Thurston, R.V. 1977 Trimmed spearman-Karber method for estimating median lethal concentrations in toxicity bioassays. Environmental Science \&Technology, Washington, 11: 714-719. Correction:12: 417, 1977

[22]. Nachales, M.M., Margulius.S.P and Saligman.A.M, 1960. A colorimetric method for the estimation of succinic dehydrogenase activity. J.Biol.Chem.,235:499-503.

[23]. Duncan,B.D.1957.Duncan's multiple range test for correlated and hetenoscedastic mean.Biometrics.13:359-364.

[24]. Sontakke and Jadhav,1997.Changes in the acid alkaline phosphatase activity in the tissue Thiara tuberculata after exposure to heavy metals.Ind.J.Environ \& Toxicol,7(1) :32-35.

[25]. More,T.G.,Rajput, R.A. and Bandela,N.M.2005.Effect of heavy metal on enzyme succinic dehydrogenase of freshwater bivalve,Lamellidenus marginalis.Poll.Res.24:675-679.

[26]. Harper,H.A., Rodwell,V.W. and Mayes,P.A.1978.Review of physiological chemistry.19th ed.Large Medical Publication.California.

[27]. Sastry, K.V. and Agrawal.M.K, 1997. Histochemical localization of alkaline and acid phosphatases in the kidney of Ophiocephalus punctatus treated with mercuric chloride. folia. Histochem. Et. Cytochem., 15: 243-247

[28]. Mary Chandravathy V, and Reddy S.L.N., 1995. In vivo effects of lead acetate on dehydrogenase acetates and metabolities in the freshwater fish. J. Ecotoxicol. Environ. Monit. 5(2) :107-111.

[29]. James, R., Sampath.K and Alagurathinam.S, 1996. Effects of lead on respiratory enzyme activity glycogen and blood sugar levels of the teleost, Oreochromis mossambicus (peters) 
during accumulation and depuration. Asian fish. Sci., 9:86-99.

[30]. Alam, M.N. and Noor-Alam,M.D.1989.Toxicity of Metacid and Ekalux to tadpoles of skipper frog Rana cyanophlyctis.J.Eco.Biol.3:163-167.

[31]. Kabeer Ahmed, I., Jagannatha Rao, KS. and Ramana Rao, KV. (1981). Effect of malathion exposure on some physiological parameters of whole blood and on tissue cations of teleost, Tilapia mossambica. J. Biol. Sci., 3:17-21.

[32]. Rajamanickam, C., 1992. Effect of heavy metal copper on the biochemical contents, bioaccumulation and histology of the selected certain in the freshwater fish, Mystus vittatus (bloch)., Ph.D. Thesis. Annamalai University, India.

[33]. Radhkrishnaiah, K., Venkataramana P. Suresh ,A . and Sivaramakrishnan, B. 1992. Effects of lethal and Sublethal concentration of copper on glycolysis in liver and musicle of fresh water teleost, Labeo rohita (Ham). J. Environ Biol.139(1);063-068.

[34]. Rashed.M.N (2001). Monitoring of environmental heavy metals in fish from Nasser Lake. Environ. Int. 27, 27-33.

[35]. Almeida, J.A, Novelli.E,L, Dalpaisilva.M and Junior.R.A, 2001. Environmental cadmium exposure and metabolic responses of the Nile Tilapia, Orechromis Niloticus. Environ. Poll., 114(2) :169-75. 